Historic, Archive Document

Do not assume content reflects current scientific knowledge, policies, or practices. 



\section{THE FENWICK GARDENS}

C. C. Miller. MANAGER

FLOWIRETLB SPECSALTSWS

GROWERS OF DAHLIAS AND PEONIES
iปT.

MAR 131931 t

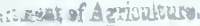

Box 212

Salem, New Jersey, U. S. A.

February 21, 1931

\section{DAHLIA TUBERS, WHOLESALE ONLY}

Below we list the varieties of Dahlias we have to offer this season. Field grown, free from disease, carefully labeled, guaranteed true to name. Terms cash with order. If wanted Parcel Post, add postage. Otherwise, we ship Express, collect. Packing absolutely perfect.

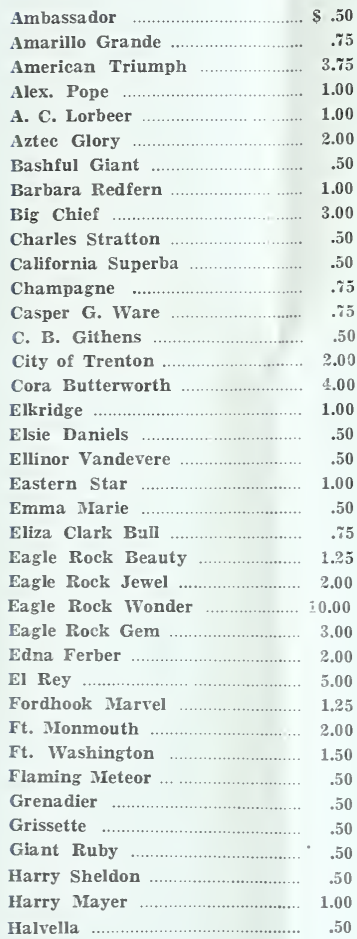

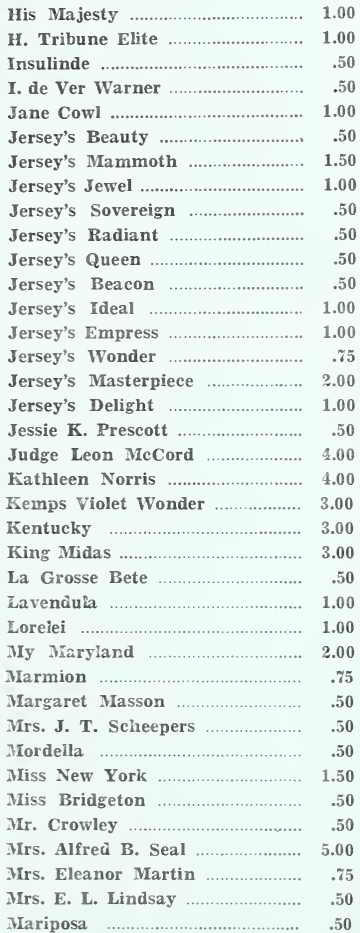

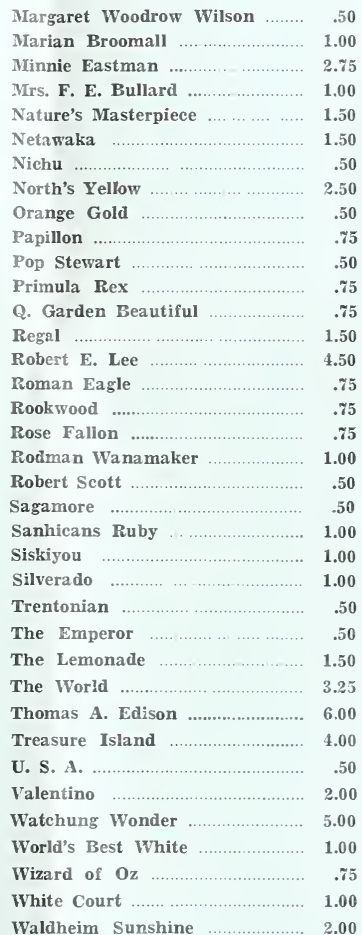

We are in a locality where many Dahlias are grown. We are large growers ourselves. If you do not see listed above what you want, write us. We can possibly quote attractive prices on your requirements.

DAHLIA SEED-We offer carefully selected seed at $\$ 1.00$ a package, one-third our own growing, one-third California grown and one-third imported from England. Each package equally balanced. Six packages for Five Dollars. Quantity limited. Order early. 
